\title{
А.А. Требенок, А.В. Хандогина \\ К ВОПРОСУ О МЕЖДУНАРОДНОМ СОТРУДНИЧЕСТВЕ В ОБЛАСТИ ПОДГОТОВКИ КАДРОВ ПРАВООХРАНИТЕЛЬНЫХ ОРГАНОВ
}

$\mathrm{y}$

читывая прогрессирующие темпы развития качественных и количественных характеристик преступности, мировая общественность в полной мере осознает насущную необходимость международного сотрудничества в данной сфере. В начале III тысячелетия преступность принимает транснациональный характер, выходит за границы государств, характеризуется все более современными методами достижения своих целей.

Доминирующей криминологической тенденцией последнего десятилетия и сегодняшних реалий является рост преступности в мире, как в целом, так и в отдельных странах с одновременным отставанием социально-правового контроля от растущей криминализации общественных отношений [1].
Лидеры ведущих государств мира на протяжении последних десяти лет постоянно выдвигали тему международного сотрудничества по борьбе с преступностью на крупнейших дискуссионных форумах (в частности, на саммите «группы восьми», саммите «Россия - $\mathrm{EC}^{1} »$ и др.).

Президент РФ В.В. Путин неоднократно подчеркивал важность и актуальность задачи консолидации международного сообщества в области борьбы с международной и организованной преступностью, с международным терроризмом, с незаконным оборотом наркотиков, и, в конечном счете, в области подготовки и переподготовки высококвалифицированных специалистов для правоохранительных органов [2].

\footnotetext{
1 Европейский Союз.
} 
Государственная политика РФ в области международного сотрудничества по подготовке и переподготовке полицейских кадров характеризуется четкостью и последовательностью решений. Одним из таких ярких примеров является достижение договоренности между Правительством Японии и Министерством внутренних дел РФ по подготовке полицейских кадров Японии и сотрудничестве в области борьбы с незаконным оборотом наркотиков (2010 г.).

Актуальным проблемам международного сотрудничества в области подготовки кадров правоохранительных органов посвящены работы Т.Ю. Алексеевой, Ю.Н. Жданова, З.С. Заитова, В.Я. Кикотя, А.А. Кобозева, А.Н. Костина, Е.Г. Ляхова, М.Г. Мелихова, П.Ю. Кириллова, А.В. Симоненко, а также труды зарубежных специалистов, таких как М. Андерсон, М. Боэр, М. Смит, Т. Томас, Б. Хебентон и др.

Как представляется, международное сотрудничество, осуществляемое в области подготовки полицейских кадров, можно рассматривать на универсальном и региональном уровнях.

На универсальном уровне сотрудничество реализуется в рамках международных межправительственных организаций, таких как Организация Объединенных Наций и международных полицейских организаций (например, Интерпол).

На региональном уровне сотрудничество осуществляется в рамках региональных межправительственных организаций, таких как Совет Европы, Ассоциация Южноазиатских народов.

В Северной и Южной Америке сотрудничество характеризуется помощью США и Канады другим государствам в подготовке и обучении полицейских кадров. США организует обучение иностранных сотрудников полиции в своих учебных центрах и Академии Федерального бюро расследований (ФБР), специалисты-практики из США проводят занятия в учебных заведениях других государств.

Европейская организация правоохранительных органов (Европол) была создана в целях повышения эфрфективности и расширения сотрудничества правоохранительных органов государств-участников Евросоюза в предупреждении и борьбе с терроризмом, незаконным оборотом наркотиков и другими формами международной организованной преступности.

В январе 1995 г. было подписано соглашение о создании Ассоциации европейских полицейских колледжей - Association of European Police
Colleges (AEPC), в которую входят полицейские колледжи и академии всех государств-участников Евросоюза [3].

Учреждение Ассоциации европейских полицейских колледжей обеспечивает единый принцип контакта для всех институтов обучения полицейских в Европе. Участники Ассоциации координируют свою деятельность при подготовке кадров полиции, сверяют подходы к обучению, распространяют передовой опыт и результаты исследований. Ассоциация также осуществляет совместные обучающие программы и сотрудничает с Международной академией правоохранительных органов в г. Будапеште.

Международная академия правоохранительных органов (International Law Enforcement Academy - ILEA) была создана в 1995 г. по соглашению правительств США и Венгрии под руководством Госдепартамента США. Это одно из первых учебных заведений, практикующих блочно-модульную технологию подготовки. Основными особенностями блочно-модульной педагогической технологии являются системность (логика и целостность процесса), управляемость (целенаправленность, ориентация на получение заранее запланированных результатов), эфффективность (интенсификация процесса обучения, соотношение затрат и результатов), воспроизводимость (возможность повторения в однотипных условиях), оптимальность (оптимизация содержания обучения, соотношения теоретической и практической подготовки) и др. [4].

Следует отметить и другие интеграционные организации и объединения в области полицейского образования, такие как Среднеевропейская полицейская академия (ее участниками являются Австрия, Венгрия, Германия, Польша, Словакия, Словения, Хорватия, Чехия). Деятельность этой академии направлена, главным образом, на подготовку специалистов по борьбе с организованной преступностью, на повышение их квалифрикации и установление прямых действенных контактов между специалистами сопредельных государств.

Северо-Балтийская академия (Дания, Исландия, Норвегия, Литва, Латвия, Эстония, Швеция) реализует более 20 различных курсов в год по актуальным проблемам правоохранительной деятельности.

В сентябре 1997 г. был образован Международный центр специальной полицейской подготовки в г. Варшаве, на базе которого обучаются 
полицейские более 20 стран Европы, в том числе и из России.

В 2000 г. по решению Совета министров ЕС был создан Европейский полицейский колледж (CEPOL), который в настоящее время выступает координирующим органом в сфере обучения сотрудников полиции, организует обучающие курсы и семинары на базе национальных учебных заведений.

Отметим, что в рамках соглашения о взаимном сотрудничестве между Великобританией и Российской Федерацией в борьбе с преступностью Лейстерский университет на протяжении последнего десятилетия активно сотрудничает с Московским университетом МВД России.

Характерным положительным примером регионального сотрудничества в области подготовки кадров для правоохранительных органов является опыт Всероссийского института повышения квалификации сотрудников МВД России (ВИПК МВД России). В июне 2006 г. в г. Минске Совет коллективной безопасности Организации Договора о коллективной безопасности (ОДКБ) принял решение о придании ВИПК МВД России статуса базового учебного заведения дополнительного профессионального образования сотрудников правоохранительных органов и специальных служб государств-членов ОДКБ в области противодействия терроризму, экстремизму, незаконному обороту наркотиков, незаконной (нелегальной) миграции, иным видам транснациональной организованной преступности, а также в сфере подготовки специалистов для миротворческих миссий и преподавательского состава учреждений образования правоохранительных органов и специальных служб государств-членов ОДКБ.

Достигнутые договоренности по подготовке и повышению квалифрикации сотрудников правоохранительных органов государств-членов ОДКБ позволили активизировать работу в данном направлении, а в последствии значительным образом расширить географию сотрудничества. ВИПК МВД России реализует программы переподготовки и повышения квалификации сотрудников правоохранительных органов стран Ближнего Востока и африканских государств.

В 2008 г. было подписано Соглашение о подготовке кадров для правоохранительных, противопожарных, аварийно-спасательных органов и специальных служб государств-членов ОДКБ.

В Соглашении в качестве правоохранительных, противопожарных, аварийно-спасательных органов вытупают специальные уполномоченные органы государств-членов Организации, основными (специальными) функциями которых являются обеспечение законности, государственной (национальной) безопасности, правопорядка, борьба с преступностью, в т.ч. с незаконным оборотом наркотиков и другими правонарушениями, а также осуществление разведывательной, контрразведывательной деятельности и иных специальных функций [5].

Академия управления МВД России также имеет большой практический опыт международного сотрудничества в области обмена опытом по подготовке полицейских кадров.

В октябре 1992 г. был подписан Договор о сотрудничестве и обмене опытом в области подготовки и повышения квалификации руководящих кадров полиции (милиции) между Академией МВД России и Высшей полицейской Академией ФРГ. Договор предусматривает такие формы сотрудничества как направление специалистов и преподавателей для чтения лекций и изучения опыта в сфере организации учебного процесса, организация прохождения стажировок слушателями и преподавателями, проведение научных исследований по различным проблемам предупреждения и борьбы с преступностью, организация научнопрактических конференций и семинаров и др.

Важной фрормой международного сотрудничества в области подготовки полицейских кадров являются международные научно-практические конференции, симпозиумы, семинары и круглые столы, посвященные данной проблеме. К таким мероприятиям относятся, в первую очередь, Международный симпозиум полиции (Forth International Police Executive Symposium - IPES), ежегодный семинар в институте повышения квалифрикации полицейских земли Северный РейнВесторалия (г. Нойс, Германия), Международная конференция руководителей полицейских ВУЗов стран Центральной и Восточной Европы.

В нашей стране такие мероприятия организовываются, как правило, во Всероссийском институте повышения квалификации сотрудников МВД России, в Академии управления МВД России, в Московском университете МВД России. На этих дискуссионных площадках ведущие специалисты-практики правоохранительных органов вырабатывают подходы и пути дальнейшего совершенствования в области сотрудничества и консолидации практического опыта подготовки сотрудников полиции. 
Таким образом, можно отметить, что развитие творческих связей между системой образовательных учреждений МВД России и зарубежных государств, обмен делегациями профессорско-преподавательского состава, заключение между ними договорных отношений указывают на позитивную тенденцию к интеграции систем профессионального образования кадров полиции зарубежных государств и органов внутренних дел РФ в мировую систему профессионального образования.

\section{Библиографический список:}

1. Арестов А.И. Уголовно-правовые и криминологические проблемы борьбы с организованной преступностью: Дисс. ... канд. юрид. наук. - М., 2006. — 186 с.

2. Путин В.В. Избранные речи и выступления. - М.: «Книжный мир», 2008. - 480 с.

3. Bill Hebenton, Terry Thomas. Policing Europe. Cooperation, conflict and control. — London, 1995. P. 125.

4. Технология модульного обучения в системе первоначальной подготовки сотрудников ОВД: Науч.метод. пособие / В.А. Иоголевич, Г.А. Казарцева; под. общ. ред. О.Д. Нациевского. - Челябинск, 2002. - C. 7-8.

5. Мелихов М.Г., Заитов 3.С. Правовые основы сотрудничества правоохранительных органов государств-членов Организации Договора о коллективной безопасности // Вестник ВИПК МВД России, № 4 (20), 2011. — С. 32-41.

\section{References (transliteration):}

1. Arestov A.I. Ugolovno-pravovye i kriminologicheskie problemy bor'by s organizovannoy prestupnost'yu: Diss. ... kand. yurid. nauk. - M., 2006. - 186 s.

2. Putin V.V. Izbrannye rechi i vystupleniya. - M.: «Knizhnyy mir», 2008. - $480 \mathrm{~s}$.

3. Bill Hebenton, Terry Thomas. Policing Europe. Cooperation, conflict and control. — London, 1995. R. 125.

4. Tekhnologiya modul'nogo obucheniya $v$ sisteme pervonachal'noy podgotovki sotrudnikov OVD: Nauch.metod. posobie / V.A. logolevich, G.A. Kazartseva; pod. obshch. red. O.D. Natsievskogo. - Chelyabinsk, 2002. - S. 7-8.

5. Melikhov M.G., Zaitov Z.S. Pravovye osnovy sotrudnichestva pravookhranitel'nykh organov gosudarstvchlenov Organizatsii Dogovora o kollektivnoy bezopasnosti // Vestnik VIPK MVD Rossii, № 4 (20), 2011. - S. 32-41. 